\title{
The Long Way of Ecolabel Scheme Acceptance in Indonesia: Case Study in Tuna Fisheries
}

\author{
Andre Notohamijoyo ${ }^{1}$, Martani Huseini ${ }^{2}$, Raldi H. Koestoer ${ }^{3}$, Syafril Fauzi ${ }^{4}$ \\ (andre.hamijoyo@gmail.com,martani0703@yahoo.com, ralkoest@yahoo.co.uk) \\ School of Environmental Science, Universitas Indonesia, FKG Building $5^{\text {th }}$ and $6^{\text {th }}$ Floor, Jalan Salemba \\ Raya No. 4, Jakarta $10430^{1}$, Faculty of Administrative Science, Universitas Indonesia, Kampus Baru UI \\ Depok $^{2}$, Coordinating Ministry of Economic Affairs, Republic of Indonesia, A. A. Maramis II Building, Jalan \\ Lapangan Banteng Timur No. 2-4, Jakarta Pusat $10710^{3}$
}

\begin{abstract}
Ecolabel scheme develop along with the growing awareness of the people about the need for the sustainable resources. The ecolabel scheme has not been of particular concern of developing countries. Unfortunately, the existing schemes are more business-oriented. High requirements and costs of certification are the main problems of implementing ecolabel in developing countries. Indonesia is a developing country that gets around this condition through the issuance of various laws and regulations that encourage the scheme that is recognized internationally especially in the fisheries sector. As the largest archipelagic country in the world, the fisheries sector has extraordinary resources as well as a threat to its sustainability, especially tuna, the highest economic value species in the world. Various government regulations have been prepared to facilitate the implementation of the ecolabel scheme for tuna fisheries. The main challenge is the stakeholder understanding of the regulations. An intensive education and dissemination process is needed to build community awareness. Implementation success depends on sustainable education process.
\end{abstract}

Keywords: Sustainability, ecolabel, tuna fisheries, dissemination, education process

\section{Introduction}

Food security has become a very strategic international issue in the past few decades. Various international cooperation forums such as ASEAN, APEC, OIC, D-8 and others discuss cooperation in food security both regionally and multilaterally. The 1996 World Food Summit defined food security as follows: "when all people at all times have access to sufficient, safe, nutritious food to maintain a healthy and active life" [1].

Food security reflects the ability of a country to provide and fulfill the food needs of its population at a reasonable level. Food security for each country faces a variety of major challenges ranging from climate change, natural disasters, industrialization, environmental damage and so on.

Fish is an important component of supporting food security in Indonesia. The Government establishes this strategic role in Law No. 18 of 2012 concerning Food. ${ }^{1}$ The increase in global fish

\footnotetext{
1 Law No. 18 year 2012 concerning Food
} 
consumption spurs hunting for fisheries commodities. The hunting encourages overfishing, overcapacity, destructive fishing, illegal, unreported and unregulated fishing (IUUF). Sustainability of fisheries resources in a country's territorial sea is a major challenge for the Government of that country including Indonesia.

Overfishing coupled with high demand from the international market raises concerns about the preservation of fish as a food source. The World Bank and FAO in their 2009 report entitled "Sunken Billion: The Economic Justification of Fisheries Reform" stated that since 2006, 75 percent of global fisheries resources were threatened with depletion or decline in stock due to excessive fishing practices and damage the environment [2].

This condition worries many parties about the scarcity of fisheries resources to meet the consumption needs of the global community. The 1992 Earth Summit became a starting point for environmentalists and activists to encourage sustainable production and consumption control mechanisms through environmental labeling or ecolabelling as one of the items in Agenda $21 .^{2}$

Various policies to overcome challenges to the sustainability of fisheries resources have ben carried out by the Government. As a developing country that has a wealth of abundant natural resources, Indonesia has great attention to its sustainability. Indonesia has adopted environmental economic instruments in legislation. Law No. 32 of 2009 concerning Management and Protection of the Environment (PPLH) regulates Environmental Economic Instruments. Definition of Environmental Economic Instruments based on its is: "Environmental economic instruments are a set of economic policies to encourage the Government both central and regional, or everyone towards the preservation of environmental functions."[3]

One of the instruments of environmental economics is the application of environmentally friendly labels. This is stated in Article 43 paragraph 3 letter c stating that the incentives and disincentives can be in the form of developing an environmentally friendly labeling system (ecolabel). As a derivative of the Law, Ministry of Environment declare the Minister of Environment Regulation No. 02 of $2014 .^{3}$

Ecolabeling schemes have developed well in various countries. The following table contains information about the ecolabel program that has been implemented in various countries.

Table 1. The Example of Ecolabel Program in Various Countries

\begin{tabular}{|c|l|c|}
\hline No. & \multicolumn{1}{|c|}{ Countries } & Ecolabel Program \\
\hline 1. & German & Blue Angel \\
\hline 2. & Australia & Environmental choice \\
\hline 3. & United States & Green Seal \\
\hline 4. & South Korea & Korea ecolabel \\
\hline 5. & Japan & Green Mark \\
\hline 6. & Singapore & Green Label \\
\hline 7. & Malaysia & Sirim Ekolabel \\
\hline
\end{tabular}

\footnotetext{
2 United Nations. (1992). United Nations Conference on Environment \& Development: Agenda 21, Rio de Janeiro, Brazil.

${ }^{3}$ Minister of Environment Regulation No. 02 of 2014
} 
In Indonesia, the fisheries ecolabel scheme has not developed much, although it has long been developing in the international market. Based on research from Notohamijoyo ${ }^{5}$, it is proven that international fisheries ecolabeling schemes cannot develop because they do not pay attention to the situation and condition of fisheries in developing countries. The scheme is also not yet understood by stakeholders in developing countries including Indonesia.

Referring to the research, it is necessary to know more about the understanding of the main fisheries stakeholders in Indonesia, namely small scale fishermen. Small-scale fishermen in Indonesia have a strategic position because based on data from the Ministry of Maritime Affairs and Fisheries, fishing vessel ownership in Indonesia at $90 \%$ is vessels under 5 Gross Ton (GT) ${ }^{6}$ This means that the structure of capture fisheries business in Indonesia is dominated by small fishermen. Table 2 below provides an overview of the structure of fishing boat ownership in Indonesia.

Table 2. The ownership of Capture Fisheries Ship in Indonesia

\begin{tabular}{|l|l|c|}
\hline No. & \multicolumn{1}{|c|}{ Category } & Number of Boat \\
\hline 1. & Total number of boat & $\mathbf{6 1 8 . 3 2 0}$ unit \\
\hline 2. & Without motor & 165.990 unit $(26,85 \%)$ \\
\hline 3. & Outboard Motors & 252.590 unit $(40,85 \%)$ \\
\hline 4. & $<5$ GT & 137.620 unit $(22,26 \%)$ \\
\hline 5. & $5-10 \mathrm{GT}$ & 38.740 unit $(6,27 \%)$ \\
\hline 6. & $10-20 \mathrm{GT}$ & 11.650 unit $(1,88 \%)$ \\
\hline 7. & $20-30 \mathrm{GT}$ & 7.620 unit $(1,23 \%)$ \\
\hline 8. & $30-50 \quad \mathrm{~T}$ & 920 unit $(0,15 \%)$ \\
\hline 9. & $50-100 \mathrm{GT}$ & 1.670 unit $(0,27 \%)$ \\
\hline 10. & $100-200 \mathrm{GT}$ & 1.180 unit $(0,19 \%)$ \\
\hline 11. & $>200 \mathrm{GT}$ & 340 unit $(0,05 \%)$ \\
\hline
\end{tabular}

Source: Statistics of Ministry of Marine Affairs and Fisheries (MOMAF), $2013^{7}$

Cilacap and Padang was chosen as a research location. Cilacap is a tuna landing site by the largest small-scale fishermen on the island of Java. This condition is ideal for this study because tuna is a commodity that is the object of this study. Padang (Bungus Fishing Port) is a tuna landing by the largest small-scale fishermen especially for tuna on the island of Sumatra. The comparison between both city will give the comprehensive result of the small scale fishermen

Table 3. Data on the Number of Ships at the Cilacap Fishery Port

\footnotetext{
${ }^{4}$ Suminto. (2011). Kajian Penerapan Ekolabel Produk di Indonesia. Pusat Penelitian dan Pengembangan Standarisasi BSN. Jurnal Standardisasi Vol. 13, No. 3: 201 - 206

${ }^{5}$ Notohamijoyo, Andre. 2016. The Implementation of Sustainable Development Principles To Seafood Ecolabel Certificate (Case Study of Marine Stewardship Council Implementation Failures in Indonesia). Dissertation. University of Indonesia.

${ }^{6}$ Statistics of Ministry of Marine Affairs and Fisheries (MOMAF), 2013

${ }^{7}$ Ibid
} 


\begin{tabular}{|c|l|c|c|c|}
\hline No. & \multicolumn{1}{|c|}{$\begin{array}{c}\text { Category and Size of } \\
\text { Ship }\end{array}$} & $\mathbf{2 0 1 4}$ & $\mathbf{2 0 1 5}$ & $\begin{array}{c}\text { Increase/Dec } \\
\text { rease }\end{array}$ \\
\hline A. & Motor Ship & 334 & 324 & -3 percent \\
\hline 1. & $11-20$ GT & 32 & 38 & 19 percent \\
\hline 2. & $21-30$ GT & 254 & 249 & -2 percent \\
\hline 3. & $31-50$ GT & 28 & 20 & -29 percent \\
\hline 4. & $51-200$ GT & 20 & 17 & -15 percent \\
\hline B. & Outboat Motor (< 10 GT) & 341 & 341 & 0 percent \\
\hline & Total (A +B) & 675 & 665 & -1 percent \\
\hline
\end{tabular}

Source: Statistic of Ministry of Marine Affairs and Fisheries (MOMAF), $2015^{8}$

The Cilacap Ocean Fishery Port is located in Tegalkamulyan Village, South Cilacap District, Cilacap Regency, Central Java Province. The exact location of the Fishery Port is 109 "01" 18.4 "BT and 07" 43'31.2 "LS, in the middle of Java on the south coast with a distance of $435 \mathrm{~km}$ from Jakarta and $568 \mathrm{~km}$ from Surabaya with access to land transportation sea and air. Cilacap PPS is located in a strategic position with WPP 573 (fishing ground area) and the largest business centers (Jakarta and Surabaya).

Table 4. Data on the Number of Ships at the Bungus Fishing Port

\begin{tabular}{|c|c|c|}
\hline No. & $\begin{array}{c}\text { Category and Size } \\
\text { of Ship }\end{array}$ & $\mathbf{2 0 1 5}$ \\
\hline 1. & $<5 \mathrm{GT}$ & 7 \\
\hline 2. & $>5-10 \mathrm{GT}$ & 20 \\
\hline 3. & $>10-20 \mathrm{GT}$ & 2 \\
\hline 4. & $>20-30 \mathrm{GT}$ & 12 \\
\hline 5. & $>30-50$ & 23 \\
\hline 6. & $>50-100$ & 0 \\
\hline
\end{tabular}

\footnotetext{
${ }^{8}$ Statistics of Ministry of Marine Affairs and Fisheries (MOMAF), 2015
} 


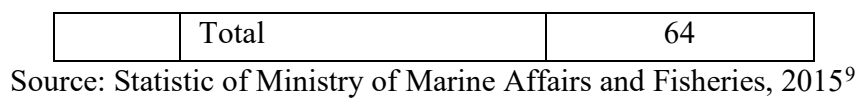

Bungus Fishing Port was developed as a tuna landing center because of this is the only fishing port that has a major commodity tuna fish on the island of Sumatra which has facilities for landing fish tuna is like a tuna processing building. The location of Bungus PPS is very strategic dealing directly with the Western Indian Ocean. However the problem with Bungus PPS is very complex. One of them decline the number of ships that are anchored at the Ocean Fishery Port (PPS) Bungus thus reducing tuna production. A decrease in the value of tuna production because it is dominated by processed quality tuna so the price is much more low compared to exports of fresh tuna.

The arresting fleet is mostly doing activities at Bungus PPS is a tuna boat measuring $>30 \mathrm{GT}$ with the dominant catch is longline tuna. In general, the types of fishing gear in Bungus PPS are identical with the type of ship used. The most dominant fishing gear in Operations at Bungus PPS include Rawai Tuna, Tonda Pancing, Pukat Cincin.

The fishermen at Bungus PPS come from local fishermen and migrant fishermen originating from regions outside West Sumatra, generally originating from Java usually a fisherman from a tuna boat. Based on the type of dominant fishing gear operating in Bungus PPS, the most dominant number of fishermen from the year 2008-2009 were fishermen purse seine (trawl ring), longline tuna and trolling fishing gear. The number of fishermen varies adjusted to the fishing gear that is operated.

\section{Problem Formulation}

Very minimal understanding of the main fisheries stakeholders, namely small scale fisheries makes it difficult to implement policies in the fisheries sector, which are issued by the Government. The ecolabeling scheme is not understood at all by fishermen. A study of appropriate programs and methods is needed to successfully implement government policies towards the interests of the fishing community in Indonesia.

\section{Material and Methods}

The methodology used in this research is the study of government policy literature in the field of marine and fisheries especially tuna fisheries management along with interviews with fishing communities in Cilacap Regency, Central Java and Padang City, West Sumatra. Intensive interviews were also conducted with the Head of the Cilacap Fishermen Group and the Head of the Padang Fishermen Group.

The literature study and interview were conducted to see the understanding of the small-scale fishermen on government policies in sustainable tuna fisheries management, especially regarding

${ }^{9}$ Ibid 
the implementation of the fisheries ecolabel scheme. Sampling of respondents was carried out based on purposive sampling. The research was conducted through two stages, namely in-depth interviews with key informants and interviews with fishermen.

\section{Result}

Based on the results of a survey of 570 tuna fishing fishermen in Cilacap, it was found that none of the fishermen understood the fisheries ecolabeling scheme. Fishermen also do not understand about sustainable tuna fisheries management. Fishermen do not even follow the development of government regulations in the field of marine and fisheries, especially for tuna fisheries. Likewise, a survey conducted on fishermen in the city of Padang. 150 respondents of tuna fishing fishermen in the port of Bungus, Padang City said that they did not know what a fisheries ecolabel was. They do not understand about sustainable tuna fisheries management.

Fishermen only understand about tuna fishing season which is useful for managing fishing time. Nevertheless fishermen still see the need for support from the government to increase knowledge about sustainable tuna fisheries management. Fishermen also still see the need for facilitation and strengthening from the government for the ability of fishermen to manage sustainable fishing areas.

Intensive interviews were conducted with the Head of Cilacap and Padang Fishermen Group's informant. The results of the interview are presented in the following table in the next page:

Table 4. The Interview Result From Key Informant

\begin{tabular}{|c|c|c|c|}
\hline No. & Question & $\begin{array}{c}\text { Answer from Head of } \\
\text { Cilacap Fishermen } \\
\text { Group }\end{array}$ & $\begin{array}{c}\text { Answer from Head } \\
\text { of Padang } \\
\text { Fishermen Group }\end{array}$ \\
\hline 1. & $\begin{array}{l}\text { What are the types of fish } \\
\text { caught in Cilacap } \\
\text { (Padang)? }\end{array}$ & $\begin{array}{l}\text { "Different types of catch fish are } \\
\text { adapted to the catch season. There } \\
\text { are lobsters, groupers, shrimp, tuna } \\
\text { and others. At present tuna is the } \\
\text { most catch in Cilacap." }\end{array}$ & $\begin{array}{l}\text { "Tuna is the most catch in } \\
\text { West Sumatera, especially in } \\
\text { the area around Mentawai } \\
\text { Islands. Many tuna species are } \\
\text { caught in the waters around } \\
\text { the Mentawai Islands." }\end{array}$ \\
\hline 2. & $\begin{array}{l}\text { Does tuna have a season } \\
\text { too? }\end{array}$ & $\begin{array}{l}\text { "Yes, each fish has its own season } \\
\text { of catch. In Cilacap, because the } \\
\text { catch area in Indian Ocean, there } \\
\text { are many tuna species migrate } \\
\text { here." }\end{array}$ & $\begin{array}{l}\text { "Each fish has a certain time } \\
\text { to catch including tuna. Tuna } \\
\text { catches around the Mentawai } \\
\text { Islands differ in type } \\
\text { depending on the period." }\end{array}$ \\
\hline 3. & $\begin{array}{l}\text { How is the welfare of } \\
\text { fishermen in Cilacap } \\
\text { (Padang) now? }\end{array}$ & $\begin{array}{l}\text { "The welfare of fishermen still } \\
\text { depends on the quality and quantity } \\
\text { of the catch. Fishermen still depend } \\
\text { on fishing season and fish prices. } \\
\text { Currently the price of fish in } \\
\text { Cilacap still depends on the } \\
\text { interests of the entrepreneurs in the }\end{array}$ & $\begin{array}{l}\text { "At present the welfare of the } \\
\text { fishing community in Padang } \\
\text { is still below the poverty line. } \\
\text { The difficult thing is the lack } \\
\text { of ability to catch tuna located } \\
\text { in the waters around the } \\
\text { Mentawai Islands. A ship is }\end{array}$ \\
\hline
\end{tabular}




\begin{tabular}{|c|c|c|c|}
\hline & & $\begin{array}{l}\text { process of purchasing fish that are } \\
\text { caught." }\end{array}$ & $\begin{array}{l}\text { required that has capacity and } \\
\text { capability to reach the area of } \\
\text { Mentawai Islands and to } \\
\text { maintain the quality of tuna." }\end{array}$ \\
\hline 4. & $\begin{array}{l}\text { How do fishermen } \\
\text { maintain the quality of fish } \\
\text { catches? }\end{array}$ & $\begin{array}{l}\text { "Fish caught are directly sold at the } \\
\text { fish auction place (TPI) and the } \\
\text { price depends on the results of the } \\
\text { auction conducted at the TPI. Fish } \\
\text { that are not sold at TPI, are stored in } \\
\text { a cold storage." }\end{array}$ & $\begin{array}{l}\text { "The fish that are caught are } \\
\text { then directly put into cold } \\
\text { storage. The tuna caught will } \\
\text { then be processed by the } \\
\text { company. Meanwhile some } \\
\text { part have been bought by } \\
\text { several parties both } \\
\text { processing companies and } \\
\text { food stalls or restaurants." }\end{array}$ \\
\hline 5. & $\begin{array}{l}\text { Do you know about } \\
\text { sustainable } \\
\text { management? }\end{array}$ & $\begin{array}{l}\text { "We have heard it but don't know it } \\
\text { technically. We do not understand } \\
\text { at all technically about it." }\end{array}$ & $\begin{array}{l}\text { "We have heard of it but do } \\
\text { not understand its } \\
\text { implementation. We only } \\
\text { heard from the government } \\
\text { representative at the Bungus } \\
\text { port." }\end{array}$ \\
\hline 6. & $\begin{array}{l}\text { Is sustainable fisheries } \\
\text { management necessary? }\end{array}$ & $\begin{array}{l}\text { "If it can indeed encourage the } \\
\text { preservation of fisheries resources } \\
\text { it is certainly very necessary." }\end{array}$ & $\begin{array}{l}\text { "If there are benefits to the } \\
\text { preservation of fisheries } \\
\text { resources, of course it are } \\
\text { needed." }\end{array}$ \\
\hline 7. & $\begin{array}{l}\text { Do you know about the } \\
\text { fisheries } \\
\text { certificate? }\end{array}$ & $\begin{array}{l}\text { "I've heard of it but can't understand } \\
\text { it technically. There was never any } \\
\text { socialization about fisheries } \\
\text { ecolabel certificate in Cilacap." }\end{array}$ & $\begin{array}{l}\text { "We have never heard of that. } \\
\text { We also don't know the } \\
\text { benefits." }\end{array}$ \\
\hline 8. & $\begin{array}{l}\text { Is an ecolabel certificate } \\
\text { required? }\end{array}$ & $\begin{array}{l}\text { "For fishermen, if the benefits of } \\
\text { the ecolabel certificate can be } \\
\text { explained concretely, then the } \\
\text { fisherman will join the ecolabel } \\
\text { certificate program. Clean and clear } \\
\text { information will enable fishermen } \\
\text { to understand and practice it." }\end{array}$ & $\begin{array}{l}\text { "If the certification only } \\
\text { makes it difficult for } \\
\text { fishermen in Padang and } \\
\text { provides additional costs for } \\
\text { fishing, we will reject it. At } \\
\text { present fishermen in Padang } \\
\text { still have difficulty in fishing } \\
\text { because of capital/cost } \\
\text { constraints." }\end{array}$ \\
\hline 9. & $\begin{array}{l}\text { Do you agree that Ecolabel } \\
\text { or MSC is implemented in } \\
\text { Indonesia? }\end{array}$ & $\begin{array}{l}\text { "Fishermen never get an } \\
\text { explanation from any party related } \\
\text { to the ecolabel and MSC program. } \\
\text { Fishermen have never heard of } \\
\text { Ecolabel so they cannot express } \\
\text { their agreement or not." }\end{array}$ & $\begin{array}{l}\text { "We don't understand the } \\
\text { certificate at all. If it only } \\
\text { makes fishermen difficult, we } \\
\text { reject it." }\end{array}$ \\
\hline 10. & $\begin{array}{l}\text { Are there alternatives to } \\
\text { ecolabeling? }\end{array}$ & $\begin{array}{l}\text { "For fishermen, schemes that can } \\
\text { provide additional income to } \\
\text { fishermen and benefit the survival } \\
\text { of fishermen will be } \\
\text { wholeheartedly supported. So it is } \\
\text { with ecolabeling." }\end{array}$ & $\begin{array}{l}\text { We hope the government will } \\
\text { encourage the welfare of } \\
\text { fishermen in Padang. } \\
\text { Disseminate the information } \\
\text { to fishermen about preserving }\end{array}$ \\
\hline
\end{tabular}




\begin{tabular}{|c|c|c|c|}
\hline & & & $\begin{array}{l}\text { fisheries resources is more } \\
\text { beneficial. }\end{array}$ \\
\hline 11. & $\begin{array}{l}\text { Do you trust the national } \\
\text { ecolabel? }\end{array}$ & $\begin{array}{l}\text { "If the national ecolabel is able to } \\
\text { prove that the certificate is } \\
\text { beneficial for the survival and } \\
\text { welfare of fishermen and } \\
\text { guaranteed by the Government, } \\
\text { fishermen will support it." }\end{array}$ & $\begin{array}{l}\text { We do not understand the } \\
\text { ecolabel certificate. If indeed } \\
\text { the Government initiative is } \\
\text { beneficial for the preservation } \\
\text { of fisheries resources and the } \\
\text { welfare of fishermen, we } \\
\text { support it. }\end{array}$ \\
\hline 12. & $\begin{array}{l}\text { What are the important } \\
\text { components } \\
\text { certification? }\end{array}$ & $\begin{array}{l}\text { "As far as we know in various } \\
\text { fishing programs, we are not } \\
\text { involved enough so that fishermen } \\
\text { do not get enough information } \\
\text { about the benefits of a program } \\
\text { because it is an order from above. } \\
\text { Certification needs to involve } \\
\text { fishermen if they want to be } \\
\text { practiced and need to give a correct } \\
\text { understanding of the importance of } \\
\text { the certificate for the welfare of } \\
\text { fishermen. The point is continuous } \\
\text { communication with fishermen. " }\end{array}$ & $\begin{array}{l}\text { We do not understand the } \\
\text { certification principle. We } \\
\text { hope there will be } \\
\text { socialization to the fishing } \\
\text { community. Besides that, the } \\
\text { most important thing is how to } \\
\text { help fishermen to be able to } \\
\text { increase their lives and reduce } \\
\text { poverty. }\end{array}$ \\
\hline
\end{tabular}

Resource: Respondents' answers, processed by researchers

Based on the results of the interview, the fishermen's understanding of the ecolabeling scheme is still very minimal. Fishermen also do not understand about sustainable fisheries management. Fishermen understand about catching adjustments in certain seasons. Nevertheless, fishermen support the Government's policy if it provides benefits to the fishing community.

Fishermen also support the Government's policy in the field of ecolabeling if it provides benefits economically and ecologically. Fishermen need a special approach from the Government in the form of assistance in fishing and post-capture activities. The selling price of fish carried out in the auction process at the fish landing place (TPI) also largely determines the benefits that can be received by fishermen. Likewise, the involvement of the fishing community after the arrest.

\section{Discussion}

As a government agency authorized to issue policies and also facilitate stakeholders in the maritime and fisheries sector, especially small fishermen, the Ministry of Maritime Affairs and Fisheries needs to encourage the strengthening of stakeholder information on policies issued. The Ministry of Maritime Affairs and Fisheries (MOMAF) is also an authorized agency in the management of fisheries resources in Indonesia.

The pillars of marine and fisheries development at present are sovereignty, sustainability and prosperity. The three pillars support the initiation of ecolabeling because the three pillars are in line with the principles of sustainable development namely environmental protection, economic benefits 
and socially inclusive. MOMAF policy is translated into various laws and regulations that support the existence of three pillars of marine and fisheries development.

MOMAF issued Minister of Maritime Affairs and Fisheries Regulation No. 107 of 2015 concerning the tuna fisheries management plan/RPP TCT ${ }^{10}$. The Ministerial Regulation mandates the establishment of an environmentally friendly capture fisheries certificate for tuna tuna tuna fisheries. The certificate will encourage sustainable fisheries management efforts. The Ministerial Regulation is in line with the National Capture Fisheries Management Architecture document issued by the CTF in $2016 .{ }^{11}$ The document is listed in item 5 on strengthening fisheries diplomacy where to improve the national standards of CCRF-based fishing need to be encouraged by certification and traceability systems national fish catches.

The legal basis for the national fisheries ecolabeling scheme is a factor that strengthens the foundation for fisheries ecolabeling. The support of government regulations related to fisheries ecolabeling is not yet widely known by the fishing community, especially small fishermen. The implementation of the fisheries ecolabel scheme will be difficult to implement without understanding from the stakeholders of the fisheries sector, especially small scale fishermen.

The readiness of government regulations to support the fisheries ecolabel scheme is in line with research conducted by Gulbrandsen ${ }^{12}$ which concludes the need for strong government regulation support for the implementation of an ecolabel scheme. Gulbrandsen [3] states that "certification is not enough to overcome the decline in fish stocks". In contrast, government regulations on marine reserves, restrictions on access to fish resources, strict distributive schemes and restrictions on IUU Fishing must be part of the solution. Ecolabel certification must be integrated with strong government regulations.

Support from small fishermen as the main stakeholders in the sustainable management of fisheries resources needs to be the main concern of the government. Based on research from Notohamijoyo ${ }^{13}$ it was found that the support of stakeholders including fishermen to the national fisheries ecolabel scheme was very large to reach 90.91 percent.

The high level of acceptance from respondents in the fisheries ecolabel model reflects the high level of respondents' trust in the government as an institution. It is also in line with the research from Notohamijoyo ${ }^{14}$. However, current research shows that fishermen's low understanding of ecolabel schemes makes it difficult to implement fisheries ecolabel schemes in Indonesia. Information dissemination, education, training and assistance for fishermen are needed to implement the ecolabel scheme in Indonesia.

The high level of acceptance from respondents in the fisheries ecolabel model reflects the high level of respondents' trust in the government as an institution. However, current research shows that fishermen's low understanding of ecolabel schemes makes it difficult to implement fisheries ecolabel schemes in Indonesia. Information dissemination, education, training and assistance for fishermen are needed to implement the ecolabel scheme in Indonesia.

10 Minister of Maritime Affairs and Fisheries Regulation No. 107 of 2015 concerning the tuna fisheries management plan (RPP TCT)

${ }^{11}$ National Capture Fisheries Management Architecture, Ministry of Marine Affairs and Fisheries, 2016

12 Gulbrandsen, H. Lars. (2009). The emergence and effectiveness of the Marine Stewardship Council. Marine Policy. 33: 654-660

13 Notohamijoyo, Andre. 2016. loc.cit

${ }^{14}$ Notohamijoyo, Andre. 2018. ASEAN tuna ecolabelling (ATEL): the challenge and opportunity of the first seafood regional ecolabelling in the world. E3S Web of Conferences 74. 04004. 
Klooster's research ${ }^{15}$ proves that acceptability in addition to rigor and legitimacy is one important element in the successful implementation of an ecolabel scheme. Likewise, several references such as Kvalvik [5], Hadjimichael and Hegland ${ }^{16}$ show that the level of stakeholder acceptance in a country towards an ecolabel scheme influences the successful implementation of ecolabel in that country.

Stratoudakis et al. ${ }^{17}$ stated that specific approaches to developing countries need to be adapted to local and regional socio-economic conditions. Government assistance is needed to implement ecolabel certification in developing countries.

The implementation of fisheries ecolabeling in Indonesia cannot be seen from merely applying environmental principles but must also involve other sustainable development principles, namely economic principles and social principles. The aim is ultimately certification regulates people so that without involving them as the main actors in the process, the existence of the certificate will not be implemented properly.

\section{Conclusion}

Based on these results, MOMAF needs to develop a work plan program that encourages the implementation of the national fisheries ecolabel scheme for stakeholders, especially small fishermen. This research also provides a clear direction for MOMAF to initiate a national fisheries ecolabeling scheme that places small fishermen as the main stakeholders in Indonesia. Education and strengthening the capacity of fishermen is a chore to be done to encourage increased capacity and understanding of fishermen towards sustainable management of fisheries resources.

National fisheries ecolabeling must be a form of protection for the rights of fishermen and fisheries resources. The ecolabel will also be a form of branding Indonesian fishery products that are environmentally friendly in the global market.

\section{References}

[1] FAO \& World Bank Report. "Sunken Billion: The Economic Justification of Fisheries Reform”.Washington D.C. (2009)

[2] Gulbrandsen, H. Lars. The emergence and effectiveness of the Marine Stewardship Council. Marine Policy. 33: 654-660 (2009)

[3] Hadjimichael, Maria, Hegland, J. Troels. Really sustainable? Inherent risks of eco-labeling in fisheries. Fisheries Research. 174: 129-135 (2016)

[4] Klooster, Dan. Standardizing sustainable development? The Forest Stewardship Council's plantation policy review process as neoliberal environmental governance. Geoforum. 41: 117$129(2010)$

\footnotetext{
15 Klooster, Dan (2010). Standardizing sustainable development? The Forest Stewardship Council's plantation policy review process as neoliberal environmental governance. Geoforum. 41: 117-129.

${ }^{16}$ Hadjimichael, Maria, Hegland, J. Troels. (2016). Really sustainable? Inherent risks of eco-labeling in fisheries. Fisheries Research. 174: 129-135

${ }^{17}$ Stratoudakis, Yorgos, et al. (2016). Fisheries certification in the developing work: Locks and keys or square pegs in round holes? Fisheries Research. 182: 39-49
} 
[5] Kvalvik, Ingrid, Noestvold, Bjoerg, Young, A. James. National or supranational fisheries sustainability certification schemes? A critical analysis of Norwegian and Icelandic responses. Marine Policy. 46: 137-142 (2014)

[6] Law No. 32 year 2009 concerning Management and Protection of The Environment

[7] Law No. 18 year 2012 concerning Food

[8] Minister of Environment Regulation No. 02 of 2014

[9] Minister of Maritime Affairs and Fisheries Regulation No. 107 of 2015 concerning the tuna fisheries management plan (RPP TCT)

[10] National Capture Fisheries Management Architecture, Ministry of Marine Affairs and Fisheries, 2016

[11] Notohamijoyo, Andre. The Implementation of Sustainable Development Principles To Seafood Ecolabel Certificate (Case Study of Marine Stewardship Council Implementation Failures in Indonesia). Dissertation. University of Indonesia, (2016)

[12] Notohamijoyo, Andre. ASEAN tuna ecolabelling (ATEL): the challenge and opportunity of the first seafood regional ecolabelling in the world. E3S Web of Conferences 74. 04004 (2018)

[13] Statistics of Ministry of Marine Affairs and Fisheries (MOMAF), 2013

[14] Statistics of Ministry of Marine Affairs and Fisheries (MOMAF), 2015

[15] Stratoudakis, Yorgos, McConney, Patrick, Duncan, John, Ghofar, Abdul, Gitong, Nancy, S. Mohamed, Kolliyil, Samoilys, Melita, Symington, Keith. Bourillon, Luis. Fisheries certification in the developing work: Locks and keys or square pegs in round holes? Fisheries Research. 182: 39-49 (2016)

[16] Suminto. Kajian Penerapan Ekolabel Produk di Indonesia. Pusat Penelitian dan Pengembangan Standarisasi BSN. Jurnal Standardisasi Vol. 13, No. 3: 201 - 206 (2011)

[17] United Nations. (1992). United Nations Conference on Environment \& Development: Agenda 21, Rio de Janeiro, Brazil.

[18] World Food Summit. 1996 